\begin{tabular}{lll}
\hline Volume 6 & Nomor 1 & April 2018 \\
\hline
\end{tabular}

\title{
Evaluasi Pelaksanaan Clinical Pathway Pasien Hyperbilirubinemia Neonatus di Rumah Sakit Hermina Pandanaran Semarang
}

\author{
Edwin Sanjaya*, Tjahjono Kuntjoro**, Henry Setyawan** \\ *RS Hermina Pandanaran Semarang \\ **Fakultas Kesehatan Masyarakat, Universitas Diponegoro, Semarang. \\ Email :dr_edwin_sanjaya@yahoo.com
}

\section{ABSTRACT:}

Neonatal hyperbilirubinemia is a condition of elevated blood levels of bilirubin in newborns, both by physiological factors and non-physiologic factors, which can cause death in infants. The length of care of patients with hyperbilirubinemia neonatus in Hermina Pandanaran Hospital 4,3 day $( \pm 0,675)$ did not conform to standard determined that is 3 days. The purpose of this study is to know the reasons health workers perform or not perform procedures in accordance with the clinical pathway

The type of this research is qualitative presented explanatory design. Data collection was done by in-depth interview and observation. The main informants in this study were 3 pediatric doctors and 3 implementing nurses, and triangulation informants were medical service manager, head of installation and head of perinatology room nurse. Data analysis was done by content analysis method.

The results showed that of the 10 cases observed, the mean adherence was $92.18 \%$ $( \pm 1.77)$. Coomb and G6PD test were not performed because the examination could not be done at RS Hermina Pandanaran and only $70 \%$ of the total bilirubin reexamination was for cost reasons. Socialization has not gone well because it was only done at the beginning when entering work. No checking of facilities and infrastructure has been done regularly. No team and Standard Operating Procedures for monitoring and evaluation of Clinical pathway implementation.

It is suggested that the Hospital resocialize the Clinical Pathway that has been prepared, form a monitoring and evaluation team of Clinical Pathway implementation and make the Standard Operating Procedure monitoring and evaluation of Clinical Pathway.

Keywords: $\quad$ Clinical Pathway, Hyperbilirubinemia Neonatus

\section{PENDAHULUAN}

Hiperbilirubinemia adalah salah satu masalah kesehatan yang terjadi pada bayi baru lahir, yang ditandai dengan peningkatan total serum bilirubin dalam darah di atas $5 \mathrm{mg} / \mathrm{dl}$. Istilah hiperbilirubinemia digunakan untuk menggambarkan suatu kondisi terjadinya akumulasi jumlah bilirubin yang berlebihan dalam darah dan ditandai dengan adanya jaundice atau ikterus yang merupakan warna kekuningan pada kulit, sklera dan kuku. ${ }^{1}$ Sebuah penelitian yang dilakukan di Rumah Sakit Umum Pusat Nasional Cipto Mangunkusumo selama tahun 2003 melaporkan sebanyak 23,8\% bayi baru lahir memiliki kadar bilirubin di atas $13 \mathrm{mg} / \mathrm{dl}$ dan sebanyak 128 kematian bayi baru lahir (8,5\%) dari 1509 bayi baru 
lahir yang dirawat dengan $24 \%$ kematian terkait dengan hiperbilirubinemia. ${ }^{2}$

Rumah Sakit Hermina Pandanaran telah menetapkan Clinical pathway dalam pengelolaan kasus hiperbilirubinemia neonatus. Rata-rata lama rawat pasien hiperbilirubinemia neonatus di RS Hermina Pandanaran memiliki lama rawat sebesar 4,3 hari $( \pm 0,94)$. Hal ini menunjukkan terdapat perbedaan lama rawat pasien hyperbilirubinemia neonatus dan tidak sesuai dengan standar yang telah ditetapkan yaitu 3 hari. Terdapat variasi dalam penatalaksanaan pasien antara dokter satu dengan dokter yang lain.

Clinical pathways (CP), sebagaimana diketahui merupakan bagian penting dokumen dan alat dalam mewujudkan good clinical governance di rumah sakit. Di Indonesia, dokumen ini juga menjadi salah satu syarat yang harus dipenuhi dalam Standar Akreditasi RS versi KARS 2012. Clinical pathway berperan dalam meningkatkan kendali mutu dan kendali biaya di RS, seperti pemendekan length of stay, penurunan risiko terjadinya readmisi, komplikasi serta kematian pasien, serta hospital cost secara keseluruhan dan bukan hanya sekedar dokumen kertas yang menjadi persyaratan akreditasi. ${ }^{3}$

Berdasarkan survey pendahuluan yang dilakukan di RS Hermina Pandanaran diketahui bahwa masih ada beberapa kendala dalam pelaksanaan clinical pathway Hyperbilirubinemia neonatus yang menyebabkan lama rawat menjadi lebih panjang. Dari segi komunikasi, masih terdapat kendala dalam sosialisasi implementasi clinical pathway di RS Hermina Pandanaran, dimana tidak semua dokter anak yang merawat pasien ikut dalam rapat kelompok staf medis (KSM) anak. Dari segi evaluasi, masih belum ada tim yang khusus mengevaluasi hasil pelaksanaan clinical pathway sehingga implementasi pelaksanaan clinical pathway tidak dapat dilakukan secara berkesinambungan.

Berdasarkan studi pendahuluan di lapangan, maka peneliti tertarik untuk melakukan penelitian tentang implementasi clinical pathway pasien Hyperbilirubinemia neonatus di RS Hermina Pandanaran Semarang.

\section{METODE PENELITIAN}

Penelitian ini merupakan penelitian kualitatif yang disajikan secara explanatory design. Data primer diperoleh dengan menggunakan alat pengumpulan data berupa pedoman wawancara. Data sekunder dalam penelitian ini diperoleh dari dokumentasi laporan kegiatan yang berkaitan dengan dengan implementasi pelaksanaan clinical pathway pasien hyperbilirubinemia neonatus. Informan utama dalam penelitian ini terdiri dari 3 Dokter Spesialis Anak dan 3 perawat pelaksana. Informan triangulasi dalam penelitian ini adalah manajer pelayanan medis, kepala instalasi dan kepala perawat ruang perinatologi Rumah Sakit Hermina Pandanaran.

\section{HASIL DAN PEMBAHASAN}

Rumah Sakit Hermina Pandanaran merupakan salah satu Rumah Sakit swasta tipe $\mathrm{C}$ di Semarang dengan visi rumah sakit "Menjadikan RS Hermina Pandanaran sebagai rumah sakit yang tumbuh, sehat dan terkemuka di wilayah cakupannya dengan unggulan pelayanan ibu dan anak dan mampu bersaing di era globalisasi". Berdasarkan visi yang ditetapkan, Rumah Sakit Hermina Pandanaran mengembangkan produk unggulannya pada pelayanan perinatologi. Terdapat 2 ruang perinatologi dengan 7 tempat tidur bayi dan 8 buah lampu fototerapi. Jumlah perawat di ruang perinatologi sebanyak 13 perawat dengan 1 kepala perawat.

Dari hasil pengamatan, rata-rata lama rawat pasien hyperbilirubinemia sebelum pelaksanaan clinical pathway sebesar 4,3 hari $( \pm 0,675)$. Rata- rata kesesuaian tindakan medis dan clinical pathway sebesar 90,80 persen $( \pm 3,553)$. Setelah diberlakukannya clinical pathway, 
rata-rata lama rawat pada pasien hyperbilirubinemia neonatus sebesar 3,10 hari $( \pm 0,876)$. Rata-rata kesesuaian tindakan medis dan clinical pathway sebesar 92,18 persen $( \pm 1,77)$. Penanganan pasien sendiri sudah berjalan dengan baik tetapi untuk pelaporan hasil laporan monitoring dan evaluasi belum dilaporkan secara rutin ke dokter anak.

Evaluasi pelaksanaan clinical pathway pasien Hyperbilirubinemia Neonatus

i. Komunikasi

Berdasarkan hasil wawancara didapatkan bahwa sosialisasi pelaksanaan clincal pathway pasien hyperbilrubinemia belum dilakukan dengan baik. Sosialisasi hanya dilakukan pada saat masuk atau di awal mulai bekerja di Rumah Sakit bagi dokter. Untuk perawat sosialisasi dilakukan dari Kepala Instalasi dan Kepala perawat ke perawat pelaksana.

Hasil wawancara terhadap dokter spesialis menyatakan bahwa pemantauan dan evaluasi tidak dilakukan kepada dokter spesialis anak, untuk perawat sendiri pemantauan dilakukan oleh Kepala Instalasi dan Kepala perawat selain itu juga dilakukan monitoring dan evaluasi oleh Manajemen Rumah Sakit.

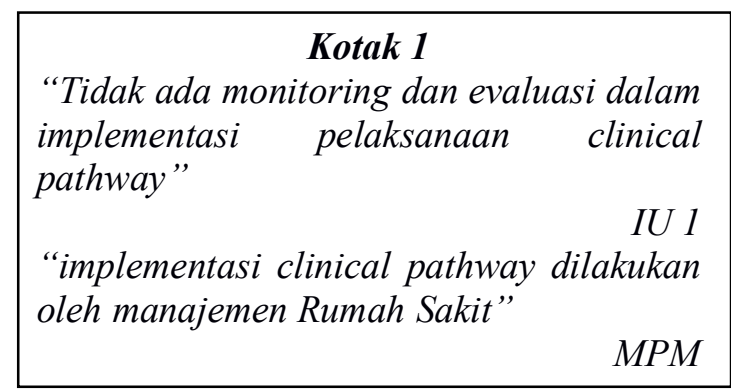

Hambatan terkait variabel komunikasi adalah tidak semua dokter anak ikut dalam rapat KMS anak sehingga penyebaran informasi tidak bisa dilakukan ke semua dokter anak.

ii. Sumber daya

Hasil wawancara mendalam
mengenai kemampuan dan
keterampilan petugas sudah cukup. Di
Rumah Sakit Hermina Pandanaran,

secara rutin dilakukan pendidikan dan pelatihan untuk perawat baik itu pelatihan di dalam atau di luar Rumah Sakit. Pendidikan dan pelatihan sudah cukup namun harus selalu mengembangkan keterampilan melalui pelatihan-pelatihan apabila ada ilmu baru. Terkadang masih ada tumpang tindih diantaranya adalah perawat memberikan penjelasan ke keluarga pasien hal yang tidak perlu dan seharusnya dilakukan oleh dokter.

Berdasarkan hasil wawnacara menunjukkan bahwa ketersediaan sarana dan prasarana dalam implementasi clinical pathway hyperbilirubenemia sudah optimal. Hasil observasi didapatkan bahwa sudah tersedia 2 ruang untuk perawatan hyperblirubinemia neonatus dan 8 buah lampu fototerapi. Tingkat kecukupan dan kelayakan sarana prasarana sudah cukup berdasarkan hasil wawancara kepada seluruh informan. Berdasarkan hasil observasi didapatkan bahwa pengecekan lampu fototerapi belum dilakukan secara rutin dan tidak diketahui lampu fototerapi sudah berapa lama digunakan. Terkait ketersediaan obat dalam penanganan pasien hyperbilrubinemia tidak membutuhkan terapi obat.

\section{Kotak 2}

Tersedia 2 ruangan untuk perawatan hyperbilirubinemia dengan 8 lampu fototerapi saya rasa sudah cukup" $M P M$

"sudah cukup, sudah memadahi" IU 3

\section{iii. Disposisi}

Terkait dengan kepatuhan petugas kesehatan dalam implementasi clinical pathway belum berjalan optimal hal ini sesuai dengan hasil audit yang telah dilakukan ditemukan bahwa dari 10 kasus yang di lakukan audit, tidak ada kasus yang diterapi sesuai dengan clinical pathway. Rata-rata kepatuhan 
clinical pathway sebesar $92,18 \%$. Ratarata rawat inap 3,1 hari dengan standar deviasi 0,876 .

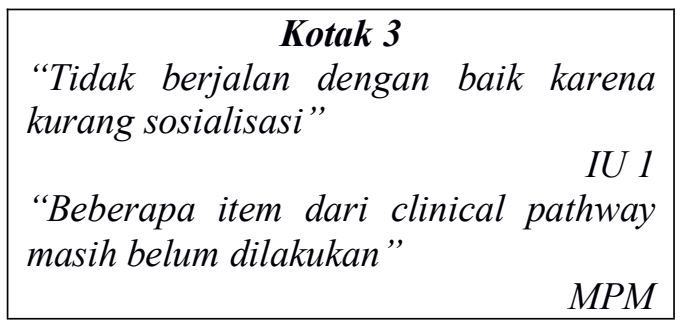

\section{iv. Struktur birokrasi}

Berdasarkan hasil penelitian didapatkan bahwa sikap petugas dalam implentasi clinical pathway pasien hyperbilirubinemia sudah baik yaitu mendukung program rumah sakit dan digunakan sebagai pedoman dalam pengelolaan hyperbilirubinemia. Rumah sakit menunjuk Kepala Instalasi dan perawat di Ruang perinatologi sebagai penanggung jawab terhadap implementasi clinical pathway dan hal ini sudah sesuai dengan tujuan yang ada. Terkait dengan insentif bagi petugas dalam menangani hyperbilirubinemia tidak ada insentif khusus.

Evaluasi pelaksanaan clinical pathway pasien Hyperbilirubinemia Neonatus

a. Komunikasi

Pada dasarnya dalam melaksanakan komunikasi suatu program haruslah disalurkan dengan baik. Penyaluran informasi yang baik akan menghasilkan infromasi yang baik pula. Komunikasi harus diinformasikan dengan jelas agar pesan bisa tersampaikan dengan baik. Suatu implementasi komunikasinya harus jelas sehingga pelaksana dan penerima pesan mengerti apa yang menjadi tugas/tanggung jawabnya. Perintah yang diberikan dalam pelaksanaan suatu komunikasi haruslah konsisten untuk diterapkan. ${ }^{4}$

b. Sumber daya
Sumber daya manusia merupakan salah satu sumber daya yang terdapat dalam organisasi, meliputi semua orang yang melakukan aktivitas. Sumber daya manusia merupakan satu satunya sumber daya yang memiliki akal, perasaan, keinginan, kemampuan, keterampilan, dorongan, daya dan karya. Semua potensi sumber daya tersebut sangat berpengaruh terhadap upaya organisasi dalam pencapaian tujuan.

Menurut Azrul Azwar, suatu organisasi terdiri dari beberapa satuan atau anggota organisasi. Sesuai dengan fungsinya masing-masing kedudukan setiap anggota organisasi berbeda antara satu dengan yang lainnya. Perbedaan yang dimaksud terbagi menjadi 4 macam, yaitu: pimpinan utama, pimpinan menengah, pimpinan bawahan, dan pelaksana. Semakin tinggi kedudukan yang dimiliki makin dibutuhkan keterampilan manajemen, sedangkan makin rendah makin dibutuhkan keterampilan teknis. ${ }^{5}$

c. Disposisi

Salah satu bentuk disposisi adalah adanya SPO. Metode atau prosedur adalah pedoman atau acuan untuk melaksanakan tugas dan pekerjaan sesuai dengan fungsi dan alat penilaian kinerja instansi pemerintah berdasarkan indikator - indikator teknis dan prosedural sesuai dengan cara kerja, prosedur kerja, dan sistem kerja pada unit yang bersangkutan. ${ }^{4}$ Adanya SPO dimaksudkan untuk memberikan konsep yang jelas, bisa dipahami oleh semua orang dan dituangkan pada suatu dokumen prosedural. Dalam setiap kegiatan SPO merupakan salah satu implementasi kebijakan pada kasus ini clinical pathway digunakan sebagai SPO oleh petugas kesehatan dalam menangani suatu kasus. Implementasi clinical pathway pasien hyperbilirubinemia membantu memastikan bahwa asuhan yang 
diberikan setepat mungkin untuk kasus tersebut.

Apabila implementor memiliki disposisi yang baik, maka dia akan dapat menjalankan kebijakan dengan baik seperti apa yang diinginkan oleh pembuat kebijakan, ketika implementor mempunyai sikap atau perspektif yang berbeda dengan pembuat kebijakan, maka proses implementasi kebijakan juga menjadi tidak efektif. ${ }^{6}$

Struktur organisasi memiliki pengaruh yang signifikan terhadap implementasi kebijakan. Aspek struktur organisasi ini melingkupi dua hal yaitu mekanisme dan struktur birokrasi itu sendiri. Aspek pertama adalah mekanisme, dalam implementasi kebijakan biasanya sudah dibuat SPO. Struktur birokrasi di sini berkaitan dengan mekanisme pelaksanaan kegiatan, seperti SPO, supervisi dan evaluasi, serta wewenang. ${ }^{7}$

d. Struktur birokrasi

Hasil penelitian Moore dkk. Menunjukkan bahwa jika suatu rumah sakit tidak berinisiatif sendiri untuk menerapkan suatu kebijakan, maka akan ada kebutuhan nyata terhadap berbagai motivasi eksternal yang akan dibarengi dengan insentif dan sumber daya yang tepat. Hal ini biasanya terjadi dalam sistem kesehatan yang pendanaannya didominasi dari pemerintah, dimana pemerintah memiliki tanggung jawab yang tinggi atas kebijakannya, sehingga pemerintah berfungsi untuk memberikan stimulus demi kelancaran implementasi kebijakan tersebut. $^{8}$

\section{KESIMPULAN}

Kesesuaian tindakan medis yang dilakukan pada pasien Hyperbilirubinemia Neonatus dengan Clinical Pathway di RS Hermina Pandanaran sebesar 92,18\%. Tindakan yang tidak sesuai dengan clinical pathway yang ada meliputi pemeriksaan G6PD; pemeriksaan Coomb Tes karena tidak tersedianya pemeriksaan tersebut di RS Hermina Pandanaran; pemeriksaan ulang bilirubin total karena meningkatkan cost dan pemberian obat-obatan hanya dilakukan bila dicurigai ke arah kelainan sistem hepatobilier. Proses pembuatan Clinical Pathway masih terpusat di Hermina Hospital Grup, Rumah Sakit Hermina cabang hanya menerima dan melaksanakan formulir Clinical Pathway yang telah ditetapkan.

Tidak semua dokter anak yang merawat pasien Hyperbilirubinemia Neonatus mendapat sosialisasi Clinical Pathways yang ada. Sarana dan prasarana sudah cukup dalam penanganan pasien Hiperbilirubinemia neonatus, hanya pemeliharaan alat yang tidak rutin dilakukan. Tidak ada tim khusus yang bertugas dalam monitoring dan evaluasi pelaksanaan implementasi Clinical Pathways yang ada serta tidak ada Standar Prosedur Operasional dalam monitoring dan evaluasi pelaksanaan.

Berdasarkan hasil penelitian dan pembahasan penelitian, maka saran yang direkomendasikan diantaranya adalah proses pembuatan Clinical pathway seharusnya melibatkan profesional pemberi asuhan setempat di RS Hermina Pandanaran, perlu adanya sosialisasi ulang Clinical Pathway yang ada ke seluruh dokter spesialis anak yang merawat pasien Hyperbilirubinemia neonatus, dilakukan pemantauan sarana dan prasarana yang diperlukan untuk penatalaksanaan pasien Hyperbilirubinemia neonatus secara rutin, adanya Tim Monitoring dan Evaluasi untuk mengawasi pelaksanaan Clinical Pathways, dan pembuatan dan sosialisasi Standart Operasional Prosedur monitoring dan evaluasi pelaksanaan Clinical Pathways yang ada di Rumah Sakit. 


\section{UCAPAN TERIMAKASIH}

Peneliti mengucapkan terimakasih kepada Program Magister Administrasi dan Kebijakan Kesehatan, Fakultas Kesehatan Masyarakat Universitas Airlangga yang telah membantu dalam proses penyusunan artikel ini.

\section{DAFTAR PUSTAKA}

1. Porter ML, Dennis BL. Hyperbilirubinemia in The Term Newborn. USA: National Library of Medicine National Institutes of Health; Feb 15;65(4):599-606; 2002.

2. Direktorat Jendral Bina Upaya Kesehatan Kementrian Kesehatan Republik Indonesia. Pedoman Penyusunan Standar Pelayanan Kedokteran. Jakarta: Konsorsium Upaya Kesehatan Direktorat Jendral Bina Upaya Kesehatan Kementrian Kesehatan Republik Indonesia; 2014.

3. Kementerian Kesehatan Republik Indonesia. Standar Akreditasi Rumah Sakit. Jakarta: Kementrian Kesehatan Republik Indonesia; 2012.

4. Utarini, A. Mutu Pelayanan Kesehatan di Indonesia : Sistem Regulasi Responsif. Pidato Pengukuhan Jabatan Guru Besar pada Fakultas Kedokteran Universitas Gadjah Mada: 2011.

5. Azwar, Azrul. Pengantar Administrasi Kesehatan: Edisi Ketiga. Jakarta: Binarupa Aksara: 1996.

6. Wibowo. Perilaku Dalam Organisasi. Jakarta: Rajawali Press: 2016.

7. Moore, M. H. Break-Through Innovations and Continous Improvement: Two Different Models of Innovative Processes in the Public Sector. Public Money and Management, 25,43-50: 2005.

8. Sailendra, Annie. Langkah-Langkah Praktis Membuat SPO. Yogyakarta: Trans Idea Publishing:2015 